\title{
The Impact of Tourism on the Quality of Life of Communities in Tourist Destination Areas: A Systematic Review
}

\author{
Ni Made Sri Nopiyani ${ }^{1,2}$, I Md Ady Wirawan ${ }^{2,3,4 *}$ \\ ${ }^{1}$ Doctoral of Medical Sciences Study Program, Faculty of Medicine, Udayana University, Bali, Indonesia; ${ }^{2}$ Department of Public \\ Health and Preventive Medicine, Faculty of Medicine, Udayana University, Bali, Indonesia; ${ }^{3}$ Travel Medicine Research Group, \\ Health Research Centre, Udayana University, Bali, Indonesia; ${ }^{4}$ Center of Excellence in Tourism, Udayana University, Bali, \\ Indonesia
}

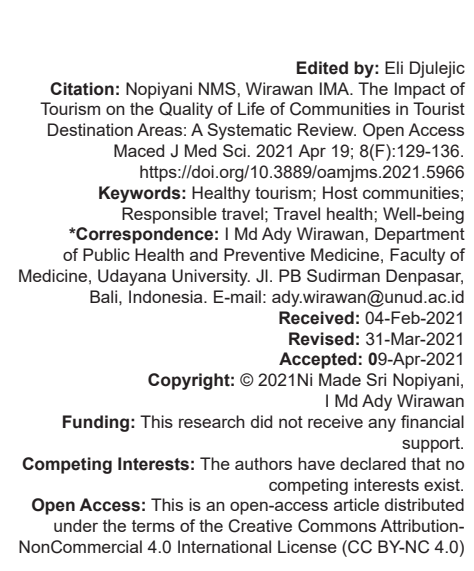

\section{Introduction}

Tourism is an industrial sector with the fastest development and is the sector that drives the world economy [1]. Previously, the main focus of research in the tourism sector was to develop strategies to optimize tourist visits and the economic benefits of destination areas [2], [3]. However, along with the development of tourism, research has begun to shift toward efforts to improve tourism sustainability [2], [4], [5], [6]. There is increasing evidence that tourism cannot only have a positive impact but can also adversely affect the economy, socio-cultural and environment in tourist destination areas [2], [7], [8], [9]. The local communities, as one of the key actors, are very much affected by tourism development [2], [6], [10]. Awareness of this fact causes a shift in the current tourism development policy agenda. Tourism development is no longer focused solely on efforts to improve the economy, but also on efforts to improve the welfare of the communities in tourist destination areas, including their quality of life (QoL) [4], [11].

More and more evidence shows that positive community perceptions about the impact of tourism on their QoL are related to stronger community support for tourism, an important requirement for tourism sustainability in destination areas [4], [6], [10], [12], [13], [14]. The importance of paying attention to the quality of lives is reflected in developments in research that focus on the impact of tourism on the QoL of community in tourist destination areas. However, there is not enough literature that has summarized the results of these studies to be able to conclude the impact of tourism on the QoL of people in tourist destination areas. This systematic review aims to determine the impact of tourism on the QoL of destination communities. In addition, an assessment was carried out on what dimensions have been used in existing studies to measure the QoL of communities in tourist destination areas. 


\section{Methods}

\section{Search strategy}

This systematic literature review was conducted in accordance with the 2015 Preferred Reporting Items for Systematic Reviews and Meta-analysis (PRISMA) guidelines [15]. The keywords used in the search were "residents' QoL" AND impacts of tourism. Articles were identified through a search of the following databases: Science Direct, Taylor Francis, EBSCO Host, Wiley Online Library, and Google Scholar, in January 2020. The search was carried out on articles published in the last 5 years, that is, 2015 to 2019 . Figure 1 shows the flowchart of literature search and selection based on PRISMA guideline.

\section{Inclusion and exclusion criteria}

The research articles included in this review were (1) focusing on the QoL of people in tourist destination areas; (2) published in 2015 to 2019; (3) published in an English peer-reviewed journal. The exclusion criteria were if it was a qualitative study, literature review, and if a full paper was not available.

\section{Data extraction}

All articles identified in the database search were exported to the Mendeley Library and duplicates were removed. The initial screening was done by reading the title and abstract. After that, a review of
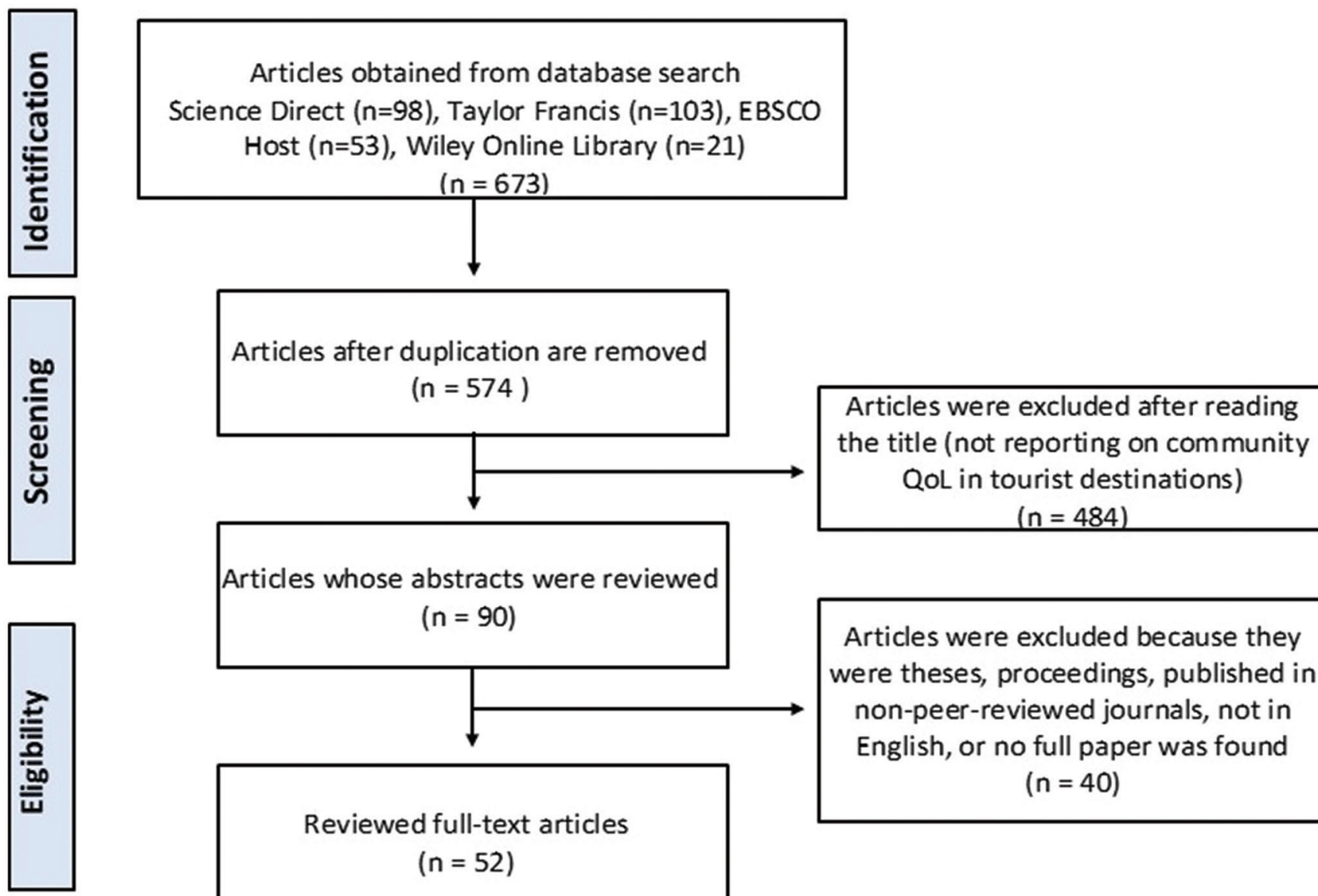

Articles whose abstracts were reviewed

$(n=90)$

Articles were excluded because they were theses, proceedings, published in non-peer-reviewed journals, not in English, or no full paper was found

$$
(n=40)
$$

Included articles

$(n=18)$

Articles were excluded because they were qualitative studies, literature reviews, did not address QoL specifically

$$
\text { ( } n=34)
$$

Figure 1: Flowchart of literature search and selection based on preferred reporting items for systematic reviews and meta-analysis guideline 
Table 1: Summary of the included articles

\begin{tabular}{|c|c|c|c|c|c|c|}
\hline No & $\begin{array}{l}\text { Author, year, } \\
\text { location }\end{array}$ & Article title & Domains of quality of life & $\begin{array}{l}\text { The impact of tourism on the quality of } \\
\text { life and its influencing factors }\end{array}$ & Research methods & Article quality \\
\hline 1 & $\begin{array}{l}\text { Biagi et al.[9] } \\
\text { Italy and Spain }\end{array}$ & $\begin{array}{l}\text { Tourism and the city: } \\
\text { The impact on residents' } \\
\text { quality of life }\end{array}$ & $\begin{array}{l}\text { Urban quality of life: } \\
\text { (1) Personal characteristics, } \\
\text { (2) environmental facilities, } \\
\text { (3) man-made facilities } \\
\text { (including health services), } \\
\text { (4) disappointment, (5) social } \\
\text { interactions, (6) tourism. } \\
\text { Each domain consists of } \\
\text { indicators of capability and } \\
\text { functioning }\end{array}$ & $\begin{array}{l}\text { - Availability of services or } \\
\text { facilities (capability) and } \\
\text { accessibility (functioning) are } \\
\text { determinants of urban quality of life } \\
\text { - The negative impact of tourism is } \\
\text { mainly felt in the aspect of accessibility } \\
\text { of services or facilities } \\
\text { - Tourism activities reduce the urban } \\
\text { quality of life of the community in } \\
\text { Alghero and Sitges }\end{array}$ & $\begin{array}{l}\text { Cross-sectional study } \\
\text { Sample size: } 923 \text { (508 in Italy and } 415 \\
\text { in Spain) }\end{array}$ & High \\
\hline 2 & $\begin{array}{l}\text { Su et al.[18] } \\
\text { China }\end{array}$ & $\begin{array}{l}\text { Perceived justice, } \\
\text { community support, } \\
\text { community identity, and } \\
\text { residents' quality of life: } \\
\text { Testing an integrative } \\
\text { model }\end{array}$ & $\begin{array}{l}\text { Global quality of life scale } \\
\text { European Organization for } \\
\text { Research and Treatment } \\
\text { of Cancer's quality of life } \\
\text { questionnaire): } \\
\text { (1) Overall health, (2) overall } \\
\text { function (physical, role, cognitive, } \\
\text { emotional, social), } \\
\text { (3) overall quality of life }\end{array}$ & $\begin{array}{l}\text { - Overall quality of life is good with } \\
\text { mean }(\mathrm{SD})=5.67 \text { (1.109) out of a } \\
\text { maximum possible value of } 7 \\
\text { - Procedural and interactional justice in } \\
\text { the implementation of tourism has a } \\
\text { positive effect on community support } \\
\text { - Procedural and distributive justice } \\
\text { in the implementation of tourism } \\
\text { has a positive effect on community } \\
\text { identification } \\
\text { - Perceptions of community support and } \\
\text { community identification contribute to } \\
\text { quality of life } \\
\text { - Perceptions of justice in the delivery of } \\
\text { tourism indirectly affect the quality of life } \\
\text { of the community }\end{array}$ & $\begin{array}{l}\text { Cross-sectional study } \\
\text { Sample size: } 453\end{array}$ & Moderate \\
\hline 3 & $\begin{array}{l}\text { Bimonte et al. } \\
{[16]} \\
\text { Italy }\end{array}$ & $\begin{array}{l}\text { Tourist season and } \\
\text { residents' life satisfaction: } \\
\text { Empirical evidence from } \\
\text { a longitudinal design } \\
\text { in a Mediterranean } \\
\text { destination }\end{array}$ & $\begin{array}{l}\text { Life satisfaction assessed: (1) } \\
\text { Satisfaction with life as a } \\
\text { whole, (2) economic situation, (3) } \\
\text { place of residence, (4) leisure, (5) } \\
\text { personal relationships, (6) } \\
\text { public services, (7) recreational } \\
\text { opportunities, (8) security }\end{array}$ & $\begin{array}{l}\text { - Community satisfaction with aspects of } \\
\text { their life (economy and family situation) } \\
\text { does not change based on the season } \\
\text { of tourist arrivals } \\
\text { - The aspect of the living environment } \\
\text { has changed in a negative direction } \\
\text { along with the increase in the number } \\
\text { of tourists } \\
\text { - During the tourist season, there is a } \\
\text { significant proportion of the population } \\
\text { experiencing a decrease in the overall } \\
\text { quality of life, job satisfaction, and } \\
\text { personal relationships } \\
\text { - The aspect of personal relationships is } \\
\text { the aspect most affected by tourism }\end{array}$ & $\begin{array}{l}\text { Longitudinal descriptive study } \\
\text { Sample size: First measurement: } 174 \text {, } \\
\text { Second measurement: } 132 \text {, } \\
\text { Third measurement: } 41\end{array}$ & Moderate \\
\hline 4 & $\begin{array}{l}\text { Eslami et al. } \\
\text { [14] } \\
\text { Malaysia }\end{array}$ & $\begin{array}{l}\text { Community attachment, } \\
\text { tourism impacts, quality } \\
\text { of life, and residents' } \\
\text { support for sustainable } \\
\text { tourism development }\end{array}$ & $\begin{array}{l}\text { Overall quality of life which } \\
\text { is measured through } 3 \\
\text { statements: (1) Life conditions, (2) } \\
\text { achievement of important things } \\
\text { in life, (3) satisfaction with life }\end{array}$ & $\begin{array}{l}\text { - Mean (SD) overall quality of } \\
\text { life }=1.56(0.818) \text { means very satisfying } \\
\text { - Community entanglement is } \\
\text { significantly associated with perceived } \\
\text { tourism impacts } \\
\text { - Perceptions of the socio-cultural } \\
\text { impacts of tourism related to the } \\
\text { non-material welfare domain } \\
\text { - Perceptions of economic impacts } \\
\text { relate to the material and non-material } \\
\text { domains } \\
\text { - Material and non-material well-being } \\
\text { are related to quality of life }\end{array}$ & $\begin{array}{l}\text { Cross-sectional study } \\
\text { Sample size: } 542\end{array}$ & Moderate \\
\hline 5 & $\begin{array}{l}\text { Kafashpor et al. } \\
\text { [19] } \\
\text { Iran }\end{array}$ & $\begin{array}{l}\text { Perception of tourism } \\
\text { development and } \\
\text { subjective happiness of } \\
\text { residents in Mashhad, } \\
\text { Iran }\end{array}$ & $\begin{array}{l}\text { Quality of life domain: (1) Living } \\
\text { conditions, (2) satisfaction with } \\
\text { life as a whole, (3) economic } \\
\text { security from work, (4) facilities } \\
\text { found in society, (5) leisure time } \\
\text { to relax }\end{array}$ & $\begin{array}{l}\text { - Tourism development affects subjective } \\
\text { happiness and the quality of life of the } \\
\text { community } \\
\text { - Perceptions of the social and } \\
\text { micro-economic impact of tourism have } \\
\text { a positive effect on people's subjective } \\
\text { happiness } \\
\text { - Perceptions of the impact of tourism } \\
\text { on culture, environment, and } \\
\text { macro-economy have a positive effect } \\
\text { on the quality of life of the community }\end{array}$ & $\begin{array}{l}\text { Cross-sectional study } \\
\text { Sample size: } 384\end{array}$ & Moderate \\
\hline 6 & $\begin{array}{l}\text { Sajad and } \\
\text { Bhat[8] } \\
\text { India }\end{array}$ & $\begin{array}{l}\text { Relationship between } \\
\text { tourism impacts and } \\
\text { residents' quality of life: } \\
\text { A study in Kashmir valley }\end{array}$ & $\begin{array}{l}\text { Three dimensions of quality of } \\
\text { life: (1) Material well-being, ( } 2) \\
\text { emotional well-being, (3) health } \\
\text { and safety }\end{array}$ & $\begin{array}{l}\text { - Respondents have a mean total quality } \\
\text { of life=3.64, classified as satisfactory. } \\
\text { Emotional well-being has the highest } \\
\text { score (3.58), material well-being (3.48), } \\
\text { and health and safety has the lowest } \\
\text { score (2.98) } \\
\text { - The three elements of the health and } \\
\text { security domain that have the lowest } \\
\text { value are security, cleanliness of } \\
\text { the living environment, the physical } \\
\text { environment in the community (air } \\
\text { quality, water) } \\
\text { - Material well-being is the best predictor } \\
\text { of people's quality of life } \\
\text { - The impact of tourism has a positive } \\
\text { and significant correlation with overall } \\
\text { quality of life }\end{array}$ & $\begin{array}{l}\text { Cross-sectional study } \\
\text { Sample size: } 384\end{array}$ & Moderate \\
\hline
\end{tabular}


Table 1: (Continued)

\begin{tabular}{|c|c|c|c|c|c|c|}
\hline No & $\begin{array}{l}\text { Author, year, } \\
\text { location }\end{array}$ & Article title & Domains of quality of life & $\begin{array}{l}\text { The impact of tourism on the quality of } \\
\text { life and its influencing factors }\end{array}$ & Research methods & Article quality \\
\hline 7 & $\begin{array}{l}\text { Al-Saad et al. } \\
\text { [24] } \\
\text { Jordan }\end{array}$ & $\begin{array}{l}\text { Residents' perceptions } \\
\text { toward tourism and its } \\
\text { impacts on their quality of } \\
\text { life in Aqaba city }\end{array}$ & $\begin{array}{l}\text { Quality of life domain: (1) } \\
\text { economy, (2) socio-cultural, (3) } \\
\text { environment. }\end{array}$ & $\begin{array}{l}\text { - The public has a higher positive } \\
\text { perception of tourism's impact on } \\
\text { the economy and socio-cultural } \\
\text { because tourism increases } \\
\text { employment opportunities, increases } \\
\text { local economies, increases cultural } \\
\text { exchange and awareness of tourists } \\
\text { - On the other hand, community's quality } \\
\text { of life is also negatively affected by } \\
\text { increases in land prices and the cost } \\
\text { of living. Apart from that, tourism also } \\
\text { contributes to traffic jams and crowds }\end{array}$ & $\begin{array}{l}\text { Cross-sectional study } \\
\text { Sample size: } 295\end{array}$ & Moderate \\
\hline 8 & $\begin{array}{l}\text { Yu et al.[10] } \\
\text { United States of } \\
\text { America }\end{array}$ & $\begin{array}{l}\text { Resident support for } \\
\text { tourism Development in } \\
\text { Rural Midwestern (USA) } \\
\text { Communities: Perceived } \\
\text { Tourism Impacts and } \\
\text { Community Quality of Life } \\
\text { Perspective }\end{array}$ & $\begin{array}{l}\text { Tourism-related community } \\
\text { quality of life dimensions: (1) } \\
\text { Overall community livability, (2) } \\
\text { overall community conditions, (3) } \\
\text { overall community services }\end{array}$ & $\begin{array}{l}\text { - The tourism-related community quality } \\
\text { of life component most affected by } \\
\text { tourism is the overall community } \\
\text { conditions } \\
\text { - Perceptions of the positive impact of } \\
\text { tourism on the local socio-cultural and } \\
\text { environment are positively related to } \\
\text { tourism-related community quality of life } \\
\text { - Perceptions of the positive impact } \\
\text { of tourism to the economy as well } \\
\text { as the negative impact of tourism } \\
\text { to the economy, socio-cultural, } \\
\text { and the environment do not affect } \\
\text { tourism-related community quality of life }\end{array}$ & $\begin{array}{l}\text { Cross-sectional study } \\
\text { Sample size: } 324\end{array}$ & Moderate \\
\hline 9 & $\begin{array}{l}\text { Su et al.[5] } \\
\text { China }\end{array}$ & $\begin{array}{l}\text { Effects of destination } \\
\text { social } \\
\text { responsibility and tourism } \\
\text { impacts on residents' } \\
\text { support } \\
\text { for tourism and perceived } \\
\text { quality of life }\end{array}$ & $\begin{array}{l}\text { Three global items of quality } \\
\text { of life: (1) Overall health, (2) } \\
\text { overall functioning (physical, role, } \\
\text { cognitive, emotional, social), (3) } \\
\text { overall quality of life }\end{array}$ & $\begin{array}{l}\text { - Destination social responsibility } \\
\text { improves community's perceptions } \\
\text { of the positive impacts of tourism but } \\
\text { has no effect on their perceptions of } \\
\text { tourism's adverse impacts } \\
\text { - Destination social responsibility has a } \\
\text { strong direct and positive relationship } \\
\text { with perceptions of quality of life and } \\
\text { community support for tourism } \\
\text { - Destination social responsibility also } \\
\text { has an indirect and positive relationship } \\
\text { to perceptions of quality of life and } \\
\text { community support for tourism. If the } \\
\text { community has a positive perception } \\
\text { of the impact of tourism, support for } \\
\text { tourism and quality of life will increase. } \\
\text { If the perception is negative, then the } \\
\text { support for tourism and quality of life } \\
\text { will also decrease }\end{array}$ & $\begin{array}{l}\text { Cross-sectional study } \\
\text { Sample size: } 292\end{array}$ & Moderate \\
\hline 10 & $\begin{array}{l}\text { Carneiro et al. } \\
\text { [20] } \\
\text { Portugal }\end{array}$ & $\begin{array}{l}\text { The influence of social } \\
\text { contact in residents' } \\
\text { Perceptions of the } \\
\text { tourism impact on their } \\
\text { quality of life: a structural } \\
\text { equation model }\end{array}$ & $\begin{array}{l}\text { The four domains of quality of } \\
\text { life: (1) Positive feelings, (2) } \\
\text { economic and social } \\
\text { opportunities, (3) public facilities } \\
\text { and services, and (4) tranquility } \\
\text { and security }\end{array}$ & $\begin{array}{l}\text { - Tourism has a positive effect on } 4 \\
\text { quality of life domains: Positive feelings, } \\
\text { economic, and social opportunities, } \\
\text { public facilities and services, and peace } \\
\text { and security } \\
\text { - Social interactions between the } \\
\text { community and tourists have } \\
\text { a significant effect on people's } \\
\text { perceptions of tourism's impact on their } \\
\text { quality of life }\end{array}$ & $\begin{array}{l}\text { Cross-sectional study } \\
\text { Sample size: } 308\end{array}$ & Moderate \\
\hline 11 & $\begin{array}{l}\text { Mathew and } \\
\text { Sreejesh[4] } \\
\text { India }\end{array}$ & $\begin{array}{l}\text { Impact of responsible } \\
\text { tourism on destination } \\
\text { sustainability and quality } \\
\text { of life of community in } \\
\text { tourism destinations }\end{array}$ & $\begin{array}{l}\text { Quality of life consists of } 8 \\
\text { domains: (1) Material welfare, (2) } \\
\text { community welfare, (3) emotional } \\
\text { well-being, (4) health, (5) } \\
\text { safety, (6) urban problems, (7) } \\
\text { crime, and (8) drug abuse. }\end{array}$ & $\begin{array}{l}\text { - Good perceptions of responsible } \\
\text { tourism significantly affect the } \\
\text { perception of the sustainability of } \\
\text { destinations. A good perception of } \\
\text { destination sustainability significantly } \\
\text { affects quality of life } \\
\text { - Perceptions of destination sustainability } \\
\text { mediate the relationship between } \\
\text { perceptions of responsible tourism and } \\
\text { quality of life }\end{array}$ & $\begin{array}{l}\text { Cross-sectional study } \\
\text { Sample size }=399\end{array}$ & Moderate \\
\hline 12 & $\begin{array}{l}\text { Ridderstaat } \\
\text { et al.[21] } \\
\text { Venezuela }\end{array}$ & $\begin{array}{l}\text { A two-way causal } \\
\text { chain between tourism } \\
\text { development and quality } \\
\text { of life in a small island } \\
\text { destination: An empirical } \\
\text { analysis }\end{array}$ & $\begin{array}{l}\text { Dimensions of quality of life: (1) } \\
\text { Work and income, (2) number of } \\
\text { hours of sleep and exercise }\end{array}$ & $\begin{array}{l}\text { - The development of tourism has a } \\
\text { direct and indirect impact on the quality } \\
\text { of life of the people } \\
\text { - The direct effect is seen in the } \\
\text { dimensions of employment and income } \\
\text { - The indirect effect is on the dimensions } \\
\text { of the amount of sleep and exercise } \\
\text { time (negative effect) }\end{array}$ & $\begin{array}{l}\text { Cross-sectional study } \\
\text { Sample size: } 454\end{array}$ & Moderate \\
\hline 13 & $\begin{array}{l}\text { Tokarchuk et al. } \\
\text { [17] } \\
\text { German }\end{array}$ & $\begin{array}{l}\text { Tourism intensity impact } \\
\text { on satisfaction with life of } \\
\text { German residents }\end{array}$ & $\begin{array}{l}\text { Satisfaction with life: (1) } \\
\text { community life, (2) material } \\
\text { well-being, (3) work, (4) } \\
\text { health, (5) relationships with } \\
\text { family and friends, (6) emotional } \\
\text { well-being, (7) environmental } \\
\text { quality, (8) personal safety }\end{array}$ & $\begin{array}{l}\text { - Mean (SD) life satisfaction = } 6.99(1.77) \\
\text { which is quite good } \\
\text { - There is a non-linear relationship } \\
\text { between tourism intensity and } \\
\text { community welfare in the working and } \\
\text { non-working groups. At low tourism } \\
\text { intensity, people's welfare is weakly } \\
\text { affected, while at a higher tourism } \\
\text { intensity the positive effect is stronger }\end{array}$ & $\begin{array}{l}\text { Cross-sectional study, Secondary } \\
\text { data German Socio-Economic } \\
\text { Panel (2000-2011) } \\
\text { Sample size: } 239.533\end{array}$ & High \\
\hline
\end{tabular}


Table 1: (Continued)

\begin{tabular}{|c|c|c|c|c|c|c|}
\hline No & $\begin{array}{l}\text { Author, year, } \\
\text { location }\end{array}$ & Article title & Domains of quality of life & $\begin{array}{l}\text { The impact of tourism on the quality of } \\
\text { life and its influencing factors }\end{array}$ & Research methods & Article quality \\
\hline 14 & $\begin{array}{l}\text { Liang and } \\
\text { Hui[22] } \\
\text { China }\end{array}$ & $\begin{array}{l}\text { Residents' quality of life } \\
\text { and attitudes toward } \\
\text { tourism development in } \\
\text { China }\end{array}$ & $\begin{array}{l}\text { Tourism quality of life domain: (1) } \\
\text { Urban problems, (2) economic } \\
\text { strength of society, (3) personal } \\
\text { and family welfare, (4) community } \\
\text { welfare, (5) way of life, (6) public } \\
\text { awareness and facilities }\end{array}$ & $\begin{array}{l}\text { - The impact of tourism (from large } \\
\text { to small): Urban problems, public } \\
\text { awareness and facilities, way of life, } \\
\text { community welfare, personal and family } \\
\text { welfare, economy }\end{array}$ & $\begin{array}{l}\text { Cross-sectional study } \\
\text { Sample size }=562\end{array}$ & Moderate \\
\hline 15 & $\begin{array}{l}\text { Woo et al. }[7] \\
\text { United States of } \\
\text { America }\end{array}$ & $\begin{array}{l}\text { Tourism impact and } \\
\text { Stakeholders' quality } \\
\text { of life }\end{array}$ & $\begin{array}{l}\text { Overall life satisfaction through } \\
6 \text { questions: (1) Satisfaction } \\
\text { with life as a whole, (2) living } \\
\text { conditions, (3) ideal life, (4) } \\
\text { achievement of important things } \\
\text { in life, (5) not wanting to change } \\
\text { anything in life, (6) happiness }\end{array}$ & $\begin{array}{l}\text { People who work in the tourism sector } \\
\text { tend to perceive more positively the } \\
\text { impact of tourism on material life (taxes, } \\
\text { living costs, costs of basic necessities, } \\
\text { income, economic security, family } \\
\text { income) and non-material (community } \\
\text { life, emotional life, health, and security) } \\
\text { than those who do not work in the } \\
\text { tourism sector } \\
\text { - Community satisfaction with the } \\
\text { material and non-material aspects of } \\
\text { life affects overall life satisfaction }\end{array}$ & $\begin{array}{l}\text { Cross-sectional study } \\
\text { Sample size: } 407\end{array}$ & Moderate \\
\hline 16 & $\begin{array}{l}\text { Suntikul et al. } \\
{[23]} \\
\text { Vietnam }\end{array}$ & $\begin{array}{l}\text { Impacts of tourism on } \\
\text { the quality of life of local } \\
\text { residents in Hue, Vietnam }\end{array}$ & $\begin{array}{l}\text { The domain of quality of life } \\
\text { used: (1) provision of recreational } \\
\text { facilities, (2) community pride, (3) } \\
\text { economic strength, (4) cultural } \\
\text { and natural preservation, (5) } \\
\text { community welfare, (6) way of life. }\end{array}$ & $\begin{array}{l}\text { - Tourism creates a sense of community } \\
\text { pride and well-being } \\
\text { - Although tourism opens up new jobs, } \\
\text { there is dissatisfaction with the quality } \\
\text { of jobs available as well as a lack } \\
\text { of community empowerment in the } \\
\text { policy-making process and participation } \\
\text { in local governance }\end{array}$ & $\begin{array}{l}\text { Cross-sectional study } \\
\text { Sample size }=480\end{array}$ & Moderate \\
\hline 17 & $\begin{array}{l}\text { Hanafiah[11] } \\
\text { Malaysia }\end{array}$ & $\begin{array}{l}\text { Responsible tourism } \\
\text { practices and quality } \\
\text { of life: Perspective } \\
\text { of Langkawi Island } \\
\text { communities }\end{array}$ & $\begin{array}{l}\text { Quality of life domain: (1) } \\
\text { emotional well-being, ( } 2 \text { ) } \\
\text { community welfare, (3) economic } \\
\text { welfare, (4) security }\end{array}$ & $\begin{array}{l}\text { - Public perception of tourism } \\
\text { development which includes economic, } \\
\text { environmental, and social aspects } \\
\text { directly affects their quality of life } \\
\text { - There is a significant relationship } \\
\text { between the impact of tourism } \\
\text { development, quality of life, and } \\
\text { responsible tourism practices. The } \\
\text { strength of the link between tourism } \\
\text { development and quality of life } \\
\text { is stronger with the existence of } \\
\text { responsible tourism practices } \\
\text { - Responsible tourism practices affects } \\
\text { the quality of life of the population }\end{array}$ & $\begin{array}{l}\text { Cross-sectional study } \\
\text { Sample size }=481\end{array}$ & Moderate \\
\hline 18 & $\begin{array}{l}\text { Woo et al.[6] } \\
\text { United States of } \\
\text { America }\end{array}$ & $\begin{array}{l}\text { Life satisfaction and } \\
\text { support for tourism } \\
\text { development }\end{array}$ & $\begin{array}{l}\text { Overall life satisfaction } \\
\text { which is measured through } 3 \\
\text { statements: (1) Life conditions, (2) } \\
\text { achievement of important things } \\
\text { in life, (3) satisfaction with life as } \\
\text { a whole }\end{array}$ & $\begin{array}{l}\text { - Public perception of the value of } \\
\text { tourism development positively } \\
\text { affects life satisfaction in the } \\
\text { material (material life, financial } \\
\text { situation, standard of living) and } \\
\text { non-material (health, emotional, } \\
\text { community) domains } \\
\text { - Satisfaction with material and material } \\
\text { domains affects overall life satisfaction. } \\
\text { Life satisfaction affects support for } \\
\text { tourism development }\end{array}$ & $\begin{array}{l}\text { Cross-sectional study } \\
\text { Sample size: } 407\end{array}$ & Moderate \\
\hline
\end{tabular}

the full paper articles that passed the initial screening was conducted. Based on the review of the full paper, it was determined which articles would be included in the systematic review.

\section{Assessment of the quality of the article}

The Strengthening the Reporting of Observational Studies in Epidemiology (STROBE) checklist was used as a guide to assess the quality of the studies reviewed. After the initial review of the articles, the 22 STROBE criteria were modified into six criteria, namely: Sample size, sampling method, response rate, measurement, statistical analysis, and limitations of the study. The scores given in the studies reviewed were in the range of $0-6$ ( 0 if none of the criteria is met, 6 if all criteria are met). Studies were labeled as low quality if the score is 2 or less, moderate quality if the score is $3-5$, and high quality if the score is 6 .

\section{Results}

\section{Study description}

This systematic review is a synthesis of 18 articles that met the eligibility criteria from 673 articles obtained from the initial search [4], [5], [6], [7] [8], [9], [10], [11], [16], [17], [18], [19], [20], [21], [22], [23], [24]. A summary of the extracted results of the 18 articles is presented in Table 1 Eslami et al. Most of the studies were conducted in Asia, and several studies were conducted in America and Europe. Almost all studies employed a cross-sectional design. Only one study by Bimonte et al. [16] used a longitudinal design, by measuring at three points in time, that is, before, at the peak, and after tourist seasons. Most of the studies used primary data collection methods in the form of questionnaire surveys by means of self-administered and interviews, which were given directly (through face to face) or indirectly (online). There is one study that used 
secondary data, that is, data from the German SocioEconomic Panel [17], a database of annual household surveys results. Most of the studies had a sample size of more than 200 people. Only the study by Bimonte et al. [16] used a sample of less than 200. Based on the modified STROBE criteria, only two studies were of high quality, and 16 were of moderate quality.

\section{Dimensions used in measuring the QoL of people in tourist destination areas}

QoL can be measured at the individual, family, and community level [2]. Most of the studies reviewed focused on QoL at the individual level. Only one study by Torkachuk used a combination of variables measured at the individual and community levels, which is at the district level [17]. The dimensions or domains used in measuring QoL varied between studies. There are studies that use overall QoL to those that use specific domains to measure QoL. Some of the domains used are very general, such as satisfaction with life conditions, achievement of important things in life, and satisfaction with life [14]. In addition, there are two studies using the measurement scale used to measure life satisfaction in cancer patients from the European Organization for the Research and Treatment of Cancer (EORTC) that explored satisfaction with health, overall functioning and overall QoL [5], [18]. Other studies have used specific domains that are theoretically related to tourism such as material well-being, employment, income, standard of living, availability of facilities and services, health, safety, security, psychological well-being, pride, personal relationships, standard of living, leisure, ecological environmental conditions, socio-cultural conditions, urban problems, community welfare, and good governance [4], [6], [9], [16], [17], [19], [20], [21], [22], [23].

\section{The impact of tourism on the QoL of people in tourist destination areas}

Not all studies contain descriptive statistics of the QoL of the people studied. Studies carried out in India, China, Malaysia, and Germany reveal that the QoL of the people in the destination areas they studied is good [5], [8], [14], [17]. A study in the Kashmir Valley, India, concludes that the social and material welfare domains have the highest average satisfaction scores. Meanwhile, health and safety are components of the QoL with the lowest satisfaction score. The three elements of the health and security domain that have the lowest value are security, cleanliness of the living environment, and the physical environment in the community (air quality, water) [8].

This review suggests that the development of tourism affects various life domains, either directly or indirectly. Tourism development can have a positive impact on the QoL of local communities. Tourism impacts local economies by increasing employment opportunities, income, and material wellbeing [8], [20], [24]. Moreover, there is an impact on socio-cultural domain because tourism increases cultural exchange and tourists' awareness of the destination area's cultural richness [20], [21], [24]. Tourism also has a positive impact on positive feelings and community pride in the region [23]. Tourism demands the availability of adequate supporting facilities. Therefore, the increased availability of public facilities is one of the impacts of tourism development that is felt by the destination communities [9], [20]. Peace and security are also perceived as a positive impact of tourism in tourist destination areas in Portugal [20].

Apart from the positive impacts of tourism, the literature review also identified several negative impacts of tourism on local communities. Tourism causes an increase in health problems, traffic jams, and crowds in urban areas [22], [24]. During the tourist season, people experience decreased satisfaction with aspects of working conditions and personal relationships [16]. The increase in tourist visits results in a high workload, an extension of work time, thereby reducing free time for socializing. This indicates that social capital is a non-material aspect that also determines the QoL of people in tourist areas. Although tourism encourages increased availability of existing facilities and services, these improvements are not necessarily accessible to local communities. Research by Biagi et al. shows that tourism decreases the accessibility of local people to existing facilities [9]. The development of tourism can also drive inflation, thereby increasing the burden on the economy, for example, by increasing land prices and the cost of living [24]. Although tourism can create new jobs, there is dissatisfaction with the quality of jobs available. Moreover, there is also dissatisfaction toward the level of community empowerment in the policy-making processes and participation in local governance [23].

The studies examined also reveal that there are moderating variables that affect the perception of the impact of tourism on the QoL of local communities. The respondents' socio-demographic characteristics, which are related to the perceived QoL, are marital status, education, and employment [10]. Study by Woo et al shows that people who work in the tourism sector tend to perceive the impact of tourism on material and non-material lives more positively than those who do not work in the tourism sector which then affects their QoL [7]. The intensity of tourism in terms of the number of tourists visiting is one of the determinants that affect the impact of tourism on the communities' QoL [16], [17]. Social interactions between destination communities and tourists have a significant impact on communities' perceptions about the impact of tourism on their QoL [20]. Perception of equity is a factor that is indirectly related to the QoL of the communities, which is mediated by community 
support and identification [18]. One of the determinants in terms of tourism management that also affects local communities' QoL is responsible tourism practices and the implementation of social responsibility in destination areas [4], [5].

\section{Discussion}

The results of this systematic review reveal that perceptions of the impact of tourism on various life domains have a direct or indirect effect on the QoL felt by communities in tourism destination areas. Existing studies show that tourism can have a positive or negative impact on the QoL of local communities. In general, the domains that are perceived as being positively affected are economic growth, employment, pride, cultural exchange, and increased availability of facilities. Meanwhile, the negatively affected domains in most of the studies were health, safety, quality of the physical environment, cost of living, accessibility to public facilities, and social relations. This systematic review also suggests that there are variables that affect the relationship between the impact of tourism on QoL such as working in the tourism sector, intensity of tourist visits, interaction of tourists and local communities, perceptions of fairness and responsible tourism management.

In several studies, there are conflicting results related to the impact of tourism on the community's QoL. Variation between these studies can be due to the phase of tourism development in the area. In the initial phase of tourism development in an area, people's perceptions of tourism and its impacts tend to be positive. However, at a more advanced stage of tourism development, people's attitudes and QoL tend to decrease [2], [6], [7].

Defining QoL is not easy because it is a subjective perception of individuals influenced by their life experiences [2], [8]. The definitions that the researchers refer to determine the domains they use to measure QoL. The use of the general domain in some studies can provide an overall picture of the QoL but can be less sensitive in capturing the QoL influenced by tourism. As a result, the QoL identified in these studies can be an overestimation or underestimation of the QoL that is actually influenced by tourism due to other influencing factors. Measuring the QoL using the global scale of the EORTC leads to an overrepresentation of the health component, and vice versa, to underrepresent the QoL of other life domains that tourism can influence. This variation in the domains or dimensions used to measure QoL makes it difficult to make comparisons between different research settings.

Measuring the QoL can be done with indicators that are subjective or objective [9], [17]. Most of the studies use subjective indicators to measure QoL, whereas the use of objective indicators is very rare. There are only two studies by Biagi et al. and Tokarchuk et al., which combine subjective and objective indicators to measure QoL. QoL is a subjective perception of individuals, related to what they feel, so that subjective measures are more widely used by existing studies.

Almost all studies on the impact of tourism on the QoL of people in destination areas use weak crosssectional designs in inferring causal relationships. The cross-sectional design does not meet the criteria for a temporal relationship to demonstrate that the currently measured QoL is the result of tourism development [25]. Future studies may use a more robust design to infer causal relationships, such as studies with longitudinal designs. However, it should be noted that longitudinal research requires more intensive resources, including funding, time, and human resources than cross-sectional research [25]. The negative impact of tourism on communities in tourist destination areas needs to be followed up because it can affect community support for tourism and threaten tourism sustainability [6], [14]. Knowing the determinants of the QoL of people in tourist destinations allows policymakers to develop appropriate strategies [26]. The implementation of responsible tourism by government and related stakeholders is one of the essential strategies to improve destination sustainability and communities' QoL.

\section{Conclusion}

Tourism can have both positive and negative impacts on the QoL of local communities. In general, the domains of QoL that are perceived to be positively affected are the economy, employment opportunities, community pride, cultural exchange, and availability of facilities. Meanwhile, the domains that are negatively affected in most studies are health, safety, quality of the physical environment, cost of living, accessibility to public facilities, and social relations. Efforts to minimize negative impacts should be undertaken to increase community support for tourism development.

\section{Authors' Contributions}

NMSN conceived the study design and conducted the searches. NMSN screened the search results and extracted data, and IMAW confirmed the extracted data. NMSN and IMAW completed the risk of bias assessments. NMSN and IMAW wrote the manuscript. All authors provided input on the study analysis and results, and critical review of the manuscript. 


\section{References}

1. UNWTO. International Tourist Arrivals Reach 1.4 Billion Two Years Ahead of Forecasts, Press Release; 2019.

2. Uysal M, Sirgy MJ, Woo E, Kim HL. Quality of life (QOL) and well-being research in tourism. Tour Manag. 2016;53:244-61. https://doi.org/10.1016/j.tourman.2015.07.013

3. Yu CP, Cole ST, Chancellor C. Assessing community quality of life in the context of tourism development. Appl Res Qual Life. 2016;11:147-62. https://doi.org/10.1007/s11482-014-9359-6

4. Mathew PV, Sreejesh S. Impact of responsible tourism on destination sustainability and quality of life of community in tourism destinations. J Hosp Tour. 2017;31:83-9. https://doi. org/10.1016/j.jhtm.2016.10.001

5. Su L, Huang S, Huang J. Effects of destination social responsibility and tourism impacts on residents' support for tourism and perceived quality of life. J Hosp Tour Res. 2018;42:1039-57. https://doi.org/10.1177/1096348016671395

6. Woo E, Kim H, Uysal M. Life satisfaction and support for tourism development. Ann Tour Res. 2015;50:84-97. https://doi. org/10.1016/j.annals.2014.11.001

7. Woo E, Uysal M, Sirgy MJ. Tourism impact and stakeholders quality of life. J Hosp Tour Res. 2018;42:260-86.

8. Sajad F, Bhat MA. Relationship between tourism impacts and residents' quality of life: A study in kashmir valley. Int J Manag Stud. 2018;5:9. https://doi.org/10.18843/ijms/v5i4(8)/02

9. Biagi B, Ladu MG, Meleddu M, Royuela V. Tourism and the city: The impact on residents' quality of life. Int J Tour Res. 2019;1:114. https://doi.org/10.1002/jtr.2326

10. Yu CP, Cole ST, Chancellor C. Resident support for tourism development in rural Midwestern (USA) communities: Perceived tourism impacts and community quality of life perspective. Sustainability. 2018;10:802. https://doi.org/10.3390/su10030802

11. Hanafiah MH, Azman I, Jamaluddin MR. Responsible tourism practices and quality of life: Perspective of Langkawi Island communities. Procedia Soc Behav Sci. 2016;222:406-13. https://doi.org/10.1016/j.sbspro.2016.05.194

12. Park K, Lee J, Lee TJ. Residents' attitudes toward future tourism development in terms of community well-being and attachment. Asia Pac J Tour Res. 2017;22:160-72. https://doi.org/10.1080/1 0941665.2016.1208669

13. Su L, Swanson SR. The effect of personal benefits from, and support of, tourism development: The role of relational quality and quality-of-life. J Sustain Tour. 2019;1:1-22.

14. Eslami S, Khalifah Z, Mardani A, Streimikiene D, Han H. Community attachment, tourism impacts, quality of life and residents' support for sustainable tourism development. J Travel Tour Mark. 2019;36(9):1061-79. https://doi.org/10.1080/105484

\subsection{9 .1689224}

15. von Elm E, Altman DG, Egger M, Pocock SJ, Gøtzsche PC, Vandenbroucke JP. The strengthening the reporting of observational studies in epidemiology (STROBE) statement: Guidelines for reporting observational studies. PLoS Med. 2007;4(10):e296. https://doi.org/10.1371/journal.pmed.0040296 PMid:25046131

16. Bimonte S, D’Agostino A, Grilli G, Pagliuca M. Tourist season and residents' life satisfaction: Empirical evidence from a longitudinal design in a Mediterranean destination. Int $\mathrm{J}$ Tour Res. 2019;21(3):323-33. https://doi.org/10.1002/jtr.2263

17. Tokarchuk O, Gabriele R, Maurer O. Tourism intensity impact on satisfaction with life of German residents. Tour Econ. 2016;22:1315-31. https://doi.org/10.1177/1354816616672356

18. Su L, Huang S, Nejati M. Perceived justice, community support, community identity and residents' quality of life: Testing an integrative model. J Hosp Tour Manag. 2019;41:1-11. https:// doi.org/10.1016/j.jhtm.2019.08.004

19. Kafashpor A, Ganji SF, Sadeghian S, Johnson LW. Perception of tourism development and subjective happiness of residents in Mashhad, Iran. Asia Pac J Tour Res. 2018;23(6):521-31. https:// doi.org/10.1080/10941665.2018.1476392

20. Carneiro MJ, Eusébio C, Caldeira A. The influence of social contact in residents' perceptions of the tourism impact on their quality of life: A structural equation model. J Qual Assur Hosp Tour. 2018;19:1-30. https://doi.org/10.1080/15280 08x.2017.1314798

21. Ridderstaat J, Croes R, Nijkamp P. A two-way causal chain between tourism development and quality of life in a small island destination: An empirical analysis. J Sustain Tour. 2016;24:1461 79. https://doi.org/10.1080/09669582.2015.1122016

22. Liang Z, Hui T. Residents' quality of life and attitudes toward tourism development in China. Tour Manag. 2016;57:56-67. https://doi.org/10.1016/j.tourman.2016.05.001

23. Suntikul W, Pratt S, Kuan WI, Wong Cl, Chan CC, Choi WL, et al. Impacts of tourism on the quality of life of local residents in Hue, Vietnam. Anatolia. 2016;27(4):405-20. https://doi.org/10.1 080/13032917.2016.1138234

24. Al-Saad S, Al-Orainat L, Al-Badarneh M, Al-Makhadmeh A. Residents' perceptions towards tourism and its impacts on their quality of life in Aqaba city. Dirasat Hum Soc Sci. 2018;45(1):229-44

25. Wang $X$, Cheng $Z$. Cross-sectional studies: Strengths, weaknesses, and recommendations. Chest. 2020;158(1S):S6571. https://doi.org/10.1016/j.chest.2020.03.012

26. Wirawan IM, Wirawan DN, Kurniasari NM, Merati KT. Trave agent and tour guide perceptions on travel health promotion in Bali. Health Promot Int. 2020;35(1):e43-50. https://doi. org/10.1093/heapro/day119

PMid:30668759 